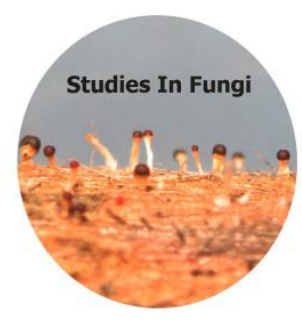

\title{
A comparative study of manglicolous lichens and their distribution inside Bhitarkanika National Park (Odisha), India
}

\author{
Panda $\mathrm{M}^{1,4 *}$, Murthy TVR ${ }^{2}$, Samal RN ${ }^{1}$, Lele $\mathrm{N}^{2}$, Patnaik $\mathrm{AK}^{3}$ and Mohan PK \\ ${ }^{1}$ Chilika Development Authority, Govt. of Odisha, India \\ ${ }^{2}$ Space Application Center (SAC/ISRO), Ahmadabad, Govt. of India \\ ${ }^{3}$ Principal Chief Conservator of Forest (PD OFSDP), Govt. of Odisha, India \\ ${ }^{4}$ Post Graduate Department of Botany, Utkal University, Odisha
}

Panda M, Murthy TVR, Samal RN, Lele N, Patnaik AK, Mohan PK 2017 - A comparative study of manglicolous lichens and their distribution inside Bhitarkanika National Park (Odisha), India. Studies in Fungi 2(1), 1-13, Doi 10.5943/sif/2/1/1

\begin{abstract}
The manglicolous lichens are a specific group of lichens which occur in association with mangrove plants. Mangrove ecosystems have limited accessibility and the lichen study in mangrove forests are less studied and reported. The present study is the first-time report on lichen diversity, their distribution and its associated host mangrove species at eight different sites within the mangrove forests of Bhitarkanika Wildlife Sanctuary and National Park (Odisha), India. The study recorded a total of 49 lichen species which belongs to 26 genera and 14 families. The comparison of growth forms showed presence of 28 species of crustose, 18 species of foliose and three species of fruticose type of lichens from the study sites. The analysis of host mangrove species showed Excoecaria agallocha as the most preferable mangrove species as it housed 38 lichen species on its surface (i.e., $45 \%$ crustose, $47 \%$ foliose, and $8 \%$ fruticose). The comparison of growth forms of the total recorded lichen species from Bhitarkanika National Park, resulted 57\% species crustose, $37 \%$ foliose and $6 \%$ of fruticose type of lichens. The mangrove species, Avicennia officinalis and lichen of the genus Chrysothrix were found as common to all the study sites. The Jaccard similarity index study of lichen species between the study sites showed Kalibhanjadiya Island and Habelikhati as more similar in comparison of lichen species composition (i.e., 0.64). The occurrence of foliose and fruticose type of lichens showed the healthy and undisturbed mangrove forest conditions at many sites within Bhitarkanika National Park.
\end{abstract}

Key words - Bhitarkanika - Diversity - Growth form - Host Mangrove - Lichens

\section{Introduction}

Mangrove ecosystems are one of the world's most species diversified and productive ecosystems. The mangrove habit is the complex of physiological adaptations enabling survival and success (Hogarth 2015). Mangroves act as nutrient sinks and protect offshore ecosystems and often referred to as bio-shields or natural sea defense (Roy et al. 2009). Mangrove forests of Bhitarkanika National Park is a diverse one and is typical of the Sundarbans (Barik \& Chowdhury 2014)

Lichen is a term for mutualistic occurrence of two lives i.e., algae and fungi and in absence of one the other can not exist (Gilbert 2004). They are found attached to rocks, soil and plant surfaces 
i.e., stem, bark, and leaves. Lichens require frequent cycling of wet and dry conditions for healthy growth and make the greatest occurrence by the onset of rainy season (Muthukumar \& Tarar 2006). In India, about 2400 lichen species included in 305 genera and 74 families have been reported to occur on various substrata (Singh \& Sinha 2010) and the state Odisha hosts 252 lichen species (Nayak et al. 2016). The group of lichens which found associated with mangrove plants (i.e., host) are called as manglicolous lichens (Logesh et al. 2013). There is no detail study on manglicolous lichens in India besides Sundarban \& some parts of Andaman \& Nicober islands with few other studies reporting lichens in mangrove ecosystem (Jagadeesh Ram 2006, Logesh et al. 2012). The mangrove and non-mangrove trees of Sundarban biosphere reserve was reported to occur 171 lichen species which belongs to 57 genera and 27 families (Jagadeesh Ram 2006). The mangrove species, like Avicennia, Lumnitzera, Barringtonia, Xylocarpus, Bruguiera, Heritiera, Ceriops, Rhizophora and Sonneratia, show excellent growth of various crustose lichens (Sethy et al. 2012, Sethy 2015). The study of lichens in Muthupet mangroves showed Excoecaria agallocha L. as the preferred mangrove species which housed eight lichen species (Logesh et al. 2013). Out of 142 recorded lichens on mangroves of Sundarban, maximum numbers of 88 (51.46\%) lichen species were recorded from the latex bearing mangrove species Excoecaria agallocha (Jagadeesh Ram 2006). It has been reported that Avicennia marina and A. officinalis did not host any lichen species (Nayaka et al. 2012). The dominant crustose lichens are from the members of Pyrenocarps, Graphidaceae, Thelotremes, Arthonoids, Bacidea, Lecidea, Lecanora (Sethy 2015). The agents of lichen destruction are the causes which disturb the ecosystems, through deforestation, agricultural practices, urbanization, pollution of air, water, soil, and exploitation of natural resources (Nash 2008).

The present study is the first attempt to estimate the lichen diversity, their distribution, comparison of growth forms and associated host mangrove species of Bhitarkanika mangrove National Park (Odisha), India.

\section{Materials \& Methods}

\section{Study site}

Bhitarkanika Wildlife Sanctuary, situated between longitudes $86^{\circ} 30^{\prime}-87^{\circ} 6^{\prime}$ E and latitude $20^{\circ} 30^{\prime}-20^{\circ} 50^{\prime} \mathrm{N}$ in Kendrapara district of Odisha along the east coast of India and occupies an area of 672 sq.km. Within the sanctuary, an area of 223 sq.km mangrove forests, rivers and creeks come under a Ramsar site and also known as Bhitarkanika National Park. Bhitarkanika National Park houses variety of mangrove species owing to different salinity gradients and varying topography in the region. The mangrove ecosystem is established by rich alluvial deposits of Brahmani, Baitarani \& the Dhamra River. The river, Brahmani played major role for the establishment of mangrove forests. The area experiences a humid tropical coastal climate of pronounced hot dry and wet seasons. The soil salinity varies significantly, Monsoon: 1-3ppt, Postmonsoon: 2-5 ppt, Winter: 4-10 ppt and Summer: 5-15 ppt at different regions within Bhitarkanika NP. The diurnal temperature varies from $15-40^{\circ} \mathrm{C}$, lowest recorded during December (Winter) and maximum during May (Summer) every year. The texture of the soil consists of more than 40\% sand and remaining is of clay and silt. The proportion sand increases from river banks towards land sites. The riverine mangroves with wide range of salinity and tidal tolerance consist of species from the genus Rhizophora, Sonneratia, Kandelia, Aegiceras and Aegialitis. The mangroves which found landwards with narrow range of salinity tolerance and low tidal range were from the genus Avicennia, Excoecaria, Heritiera, Lumnitzera, Ceriops, Xylocarpus, Cynometra, Bruguiera and many mangrove associates.

The mangrove forest of Bhitarkanika is unique in terms of both ecosystem and mangrove species diversity. The ecosystem is naturally protected due to occurrence of huge number of saltwater crocodiles i.e., Crocodylus porosus, which is frequently found in the flowing rivers, creeks and came inside the mangrove forest during high tides. 


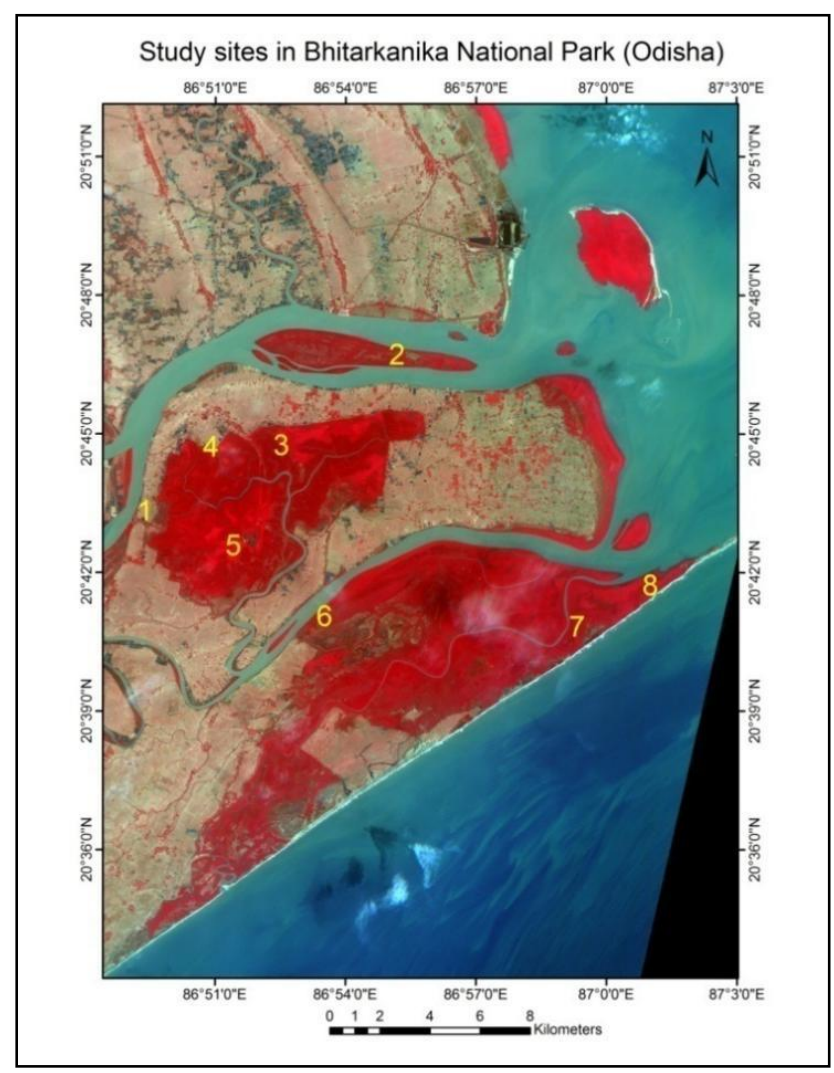

Fig.1 - Study sites in Bhitarkanika National Park (Odisha). 1. Khola. 2. Kalibhanjadiya Island. 3. Dangmal. 4. Ragarapatia. 5. Bhitarkanika. 6. Bagapatia. 7. Habelikhati. 8. Ekakula.

In present study, eight mangrove forest sites within Bhitarkanika Wildlife Sanctuary and National Park were selected (i.e., Khola, Dangmal, Bhitarkanika, Ragarapatia, Kalibhanjadiya Island, Bagapatia, Habelikhati, and Ekakula). Extensive field work was carried out on seasonal basis at different times between the years, 2014-2016. The lichen specimens were collected from the host mangrove species with GPS points and properly labeled for further study in laboratory and classified into Crustose, Foliose \& Fruticose lichen growth forms as per standard literature (Broad 1989, Muthukumar \& Tarar 2006, Rai et al. 2014b). The morphological characters of all lichens were noted in situ and photographs were taken by using the camera, Sony Alfa SLT 58Y, DSLR (Fig. 9-10). The lichen spot test was done using the chemicals on the field and in the laboratory. The species were identified by intensive study of literature (Broad 1989, Awasthi 1991, Goward 1994, Jagadeesh Ram 2006, Muthukumar \& Tarar 2006, Nash 2008, McCune 2012, Sethy et al. 2012 \& 2014, Rai et al. 2014a, Rai et al. 2014b, Dey et al. 2015, Singh et al. 2015, Weerakoon 2015). The mangrove species selected for present study were Excoecaria agallocha L., Heritiera fomes Buch.-Ham, Lumnitzera racemosa Willd., Ceriops decandra (Griff.) Ding Hou, Kandelia candel (L) Druce, Avicennia officinalis L., Avicennia marina (Forssk.) Vierh, Avicennia alba Blume, Xylocarpous granatum J.Koening, Cynomatra iripa Kostel., Rhyzophora mucronata Lam., Bruguiera cylindrica (L) Blume. The Jaccard site similarity index was calculated by using the formula given by Stiling (2012). At each site, a random sampling of 200 mangrove plants have been done for estimation of frequency of lichen occurrence and calculated as follows.

1. Frequency-Total no of mangrove plants on which one or more lichens recorded/Total no. of mangrove plants selected for study.

2. Jaccard similarity index $-\mathrm{C}_{\mathrm{j}}=\mathrm{a} /(\mathrm{a}+\mathrm{b}+\mathrm{c})$

$\mathrm{a}=$ the number of lichen species common to both sites

$\mathrm{b}=$ the number of lichen species in site $\mathrm{B}$, but not $\mathrm{A}$

$\mathrm{c}=$ the number of lichen species in site $\mathrm{A}$, but not $\mathrm{B}$ 


\section{Results}

Forty-nine manglicolous lichens were identified which belong to 14 family and 26 genera (Table 1). The comparison of site wise recorded lichens showed Habelikhati as the most lichen diversified site of Bhitarkanika NP (Tables $1 \& 2$ ). The study of lichen growth forms showed, $57 \%$ crustose, $37 \%$ foliose and $6 \%$ fruticose type of lichens (Fig. 6). The mangrove species, $E$. agallocha was found to host 38 lichen species out of which $45 \%$ crustose, $47 \%$ foliose and $8 \%$ fruticose type of lichen species (Table $2 \&$ Fig. 7). The lichens from the genus Diploicia, Phaeophyscia, Opegrapha, Parmelia, Pyxine, Ochrolechia, Lecanora, and Astrothelium were only recorded from the bark and trunk surface of E. agallocha (Table 1 \& Plate 1-2). The lichen family, physciaceae showed highest number of species than other recorded lichen family (Figs 3 ).

The mangrove plant E. agallocha was found as the most preferred mangrove species for lichen establishment as it housed highest number of lichen species on its surface, i.e. 38 (Tables 1$2 \&$ Plate 1-2). Three mangrove species, A. officinalis, A. marina and C. iripa were found to house 5 lichen species each and another two mangrove species, L. racemosa and X. granatum were found to host each with four lichen species. $H$. fomes was found to host only 3 crustose type of lichens. $C$. decandra, $R$. mucronata and $K$. candel showed presence of only crustose lichens. Lichens were rarely recorded from the mangrove species like $A$. alba and B. cylindrica (Tables $1 \& 2$ ). The study of frequency of lichen occurrence per mangrove plant at each study sites showed highest for Habelikhati, i.e., $98.5 \%$ and least at Ekakula, i.e., $36.5 \%$ (Fig. 5).

The Jaccard site similarity index study (Fig. 8) showed Habelikhati and Kalibhanjadiya Island as most similar in terms of lichen species composition with the index value 0.64 . A similar Jaccard index value (i.e., 0.52 each) was resulted for sites like Kalibhanjadiya Island vs Bagapatia and Dangmal vs Bhitarkanika. The sites which differed significantly in lichen species composition were Kalibhanjadiya Island vs Khola and Khola vs Bagapatia (Fig. 8). The sites, Habelikhati and Kalibhanjadiya Island were found to bear dense and luxuriant growth of lichens. These two sites hosted foliose and fruticose lichens on the thalli of crustose lichens (Plate 2). The fruticose lichens of the genus, Ramalina were only recorded from these two sites (Table 1).

The recorded lichens and the lichen bearing mangrove species at different study sites as follows.

Site 1 - Khola - Eight lichen species were recorded and all belong to crustose in growth form. The recorded lichens were from the genus, Arthonia, Cryptothecia, Chrysothrix, Graphis Pyrenula and Pyrrhospora (Table 1). The frequency of lichen occurrence on mangrove plants was estimated to be $45 \%$, which was second lowest (Fig. 5). E. agallocha is a rare and occasional mangrove species of this site. The site is close to human settlements and influenced by transport and interference of local people and livestock. This site was found more similar in terms of lichen species composition with Ekakula (Fig. 8).

Site 2 - Kalibhanjadiya Island - All three forms of lichens were recorded from this site (Crustose, Foliose \& Fruticose). The recorded lichen species were from the genus Arthothelium, Cryptothecia, Chrysothrix, Graphis Pyrenula, Pertusaria, Lecanora, Parmelia and Ramalina (Table 1). Thirty-two species of lichens were recorded from this site which includes 17 species of crustose, 12 species of foliose and 3 species of fruticose type of lichens (Fig. 4). E. agallocha is the most dominating mangrove species of this site. This mangrove species was found to host all three forms of lichens on its surface. Other host mangrove species include H. fomes, L. racemosa, $C$. decandra, A. officinalis, A. marina but they harbor crustose lichens only (Table 1). The frequency of lichen occurrence was $94.5 \%$, second highest after Habelikhati (Fig. 5). The site is an isolated mangrove forest area from main land by the river water of Brahmani \& Baitarani (Fig. 1). This site was found more similar in terms of lichen species composition with Habelikhati (Fig. 8).

Site 3 - Dangmal - Only two forms of lichens were recorded (Crustose \& Foliose) at Dangmal site. The lichen species recorded from this site were from the genus Anisomeridium, Arthonia, Arthothelium, Dirinaria, Chrysothrix, Graphis, Pertusaria, Parmelia, Dirinaria and Ochrolechia (Table 1). Nineteen species of lichens were recorded from this site which include 15 of species of crustose, 4 species of foliose (Table $2 \&$ Fig. 4 ). The site is mostly dominated by two 
mangrove species, i.e., E. agallocha and H. fomes with the later one hosting most of the lichens. Other mangrove species which housed lichens were $C$. iripa, $K$. candel, A. officinalis and $X$. granatum (Table $1 \&$ Table 2). The result for frequency of lichen occurrence was $71 \%$ (Fig. 5). This site was found more similar in terms of lichen species composition with Bhitarkanika (Fig. 8).

Site 4 - Ragarapatia - Ten lichen species were recorded from this site (Fig. 4). The site is dominated by mangrove species like, H. fomes, E. agallocha, S. apetala, K. candel, and $A$. officinalis. E. agallocha has been recorded to host both crustose and foliose type of lichens (Table 1 $\& 2$ ). The site is proximate to human settlements and influenced by agricultural practices. The result for frequency of lichen occurrence was 59\% (Fig. 5). This site was found more similar in terms of lichen species composition with Dangmal (Fig. 8).

Site 5 - Bhitarkanika - Sixteen lichen species were recorded which include 14 species of crustose and 2 species of foliose (Table $1 \&$ Fig. 4). The dominating mangrove species of this site are $H$. fomes, E. agallocha and A. officinalis. The result for frequency of lichen occurrence was $64 \%$ (Fig. 5). This site was found more similar in terms of lichen species composition with Dangmal (Fig. 8). The site also a part of ecotourism region and daily receive thousands of visitors along with Dangmal, every year.

Site 6 - Bagapatia - Eighteen lichen species recorded which include 9 of species of crustose, 8 species of foliose and 1 species of fruticose (Fig. 4). The site is a degraded and open mangrove site with low dense and short height mangrove species. The field data showed the site is mostly dominated by mangroves like, E. agallocha, A. marina, A. officinalis, C. decandra and two mangrove associate species, T. troupii \& T. popolnea. The mangrove species, E. agallocha was found to house all three forms of lichens at this site (Table 1). The result for frequency of lichen occurrence was 76\% (Fig. 5). This site was found more similar in terms of lichen species composition with Kalibhanjadiya Island (Fig. 8). Field information showed the site is proximate to rice cultivated agricultural lands and thought to be influenced by use of pesticides and fertilizers for enhancing agriculture yield.

Site 7 - Habelikhati - The site was found to be the most diverse and dominant lichen bearing site of Bhitarkanika National Park. Forty lichen species were recorded from this site out of the present record of 49 lichen species of Bhitarkanika National Park (Table 1 \& Fig. 4). The growth form study resulted 22 species of crustose, 15 species of foliose and 3 species of fruticose type of lichens (Fig. 4). The fruticose type of lichens were recorded only from the surface of mangrove plant E. agallocha and A. marina (Table $1 \&$ Plate 2). The fruticose lichens belong to the lichen genus Ramalina. The mangrove species, E.agallocha was found as the single most dominating lichen bearing mangrove species as it housed a total of 38 lichen species (Table 2). The result for frequency of lichen occurrence was $98.5 \%$ which was highest than any other study sites (Fig. 5). This site was found more similar in terms of lichen species composition with Kalibhanjadiya Island (Fig. 8). This site is situated away from human settlement and not influenced by anthropologic activity.

Site 8 - Ekakula -The area is situated very proximate to Bay of Bengal and more influenced by tidal sea water in comparison to other sites of Bhitarkanika NP (Fig. 1). Thirteen lichen species were recorded from this site which includes 7 crustose and 6 foliose types of lichens (Table $1 \&$ Fig. 4). The site was found to be dominated by mangrove species of the genus Rhizophora, Sonneratia, Avicennia and understory species like Kandelia, Aegialitis and Ceriops. The lichen occurrence on surface of these mangroves was found to be very low. Offshore forests, away from sea were found to have good patch of E. agallocha which showed growth of lichens but not as frequent as at Habelikhati. The result for frequency of lichen occurrence was $36.5 \%$ which was lowest among the study sites (Fig. 5). This site was found more similar in terms of lichen species composition with site, Khola (Fig. 8). 


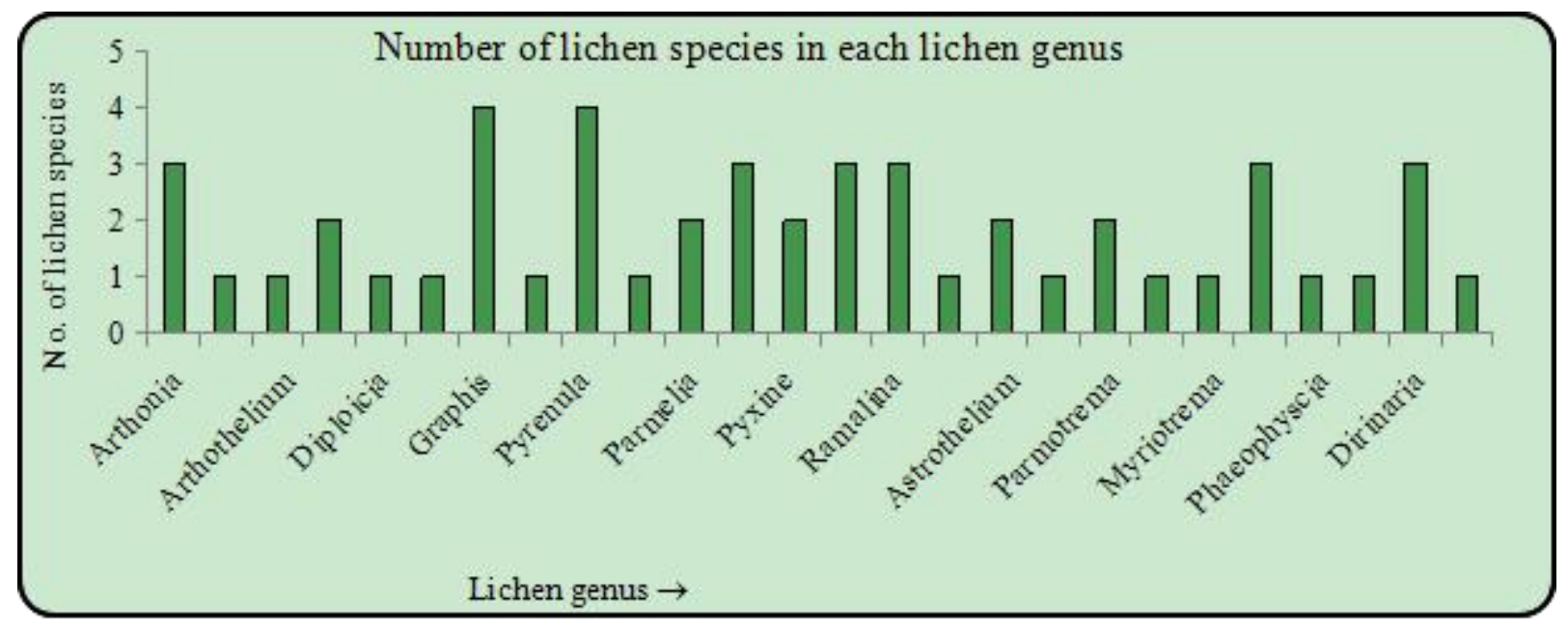

Fig. 2 - Recorded lichen genus and number of species of that genus, Bhitarkanika NP, (Odisha), India

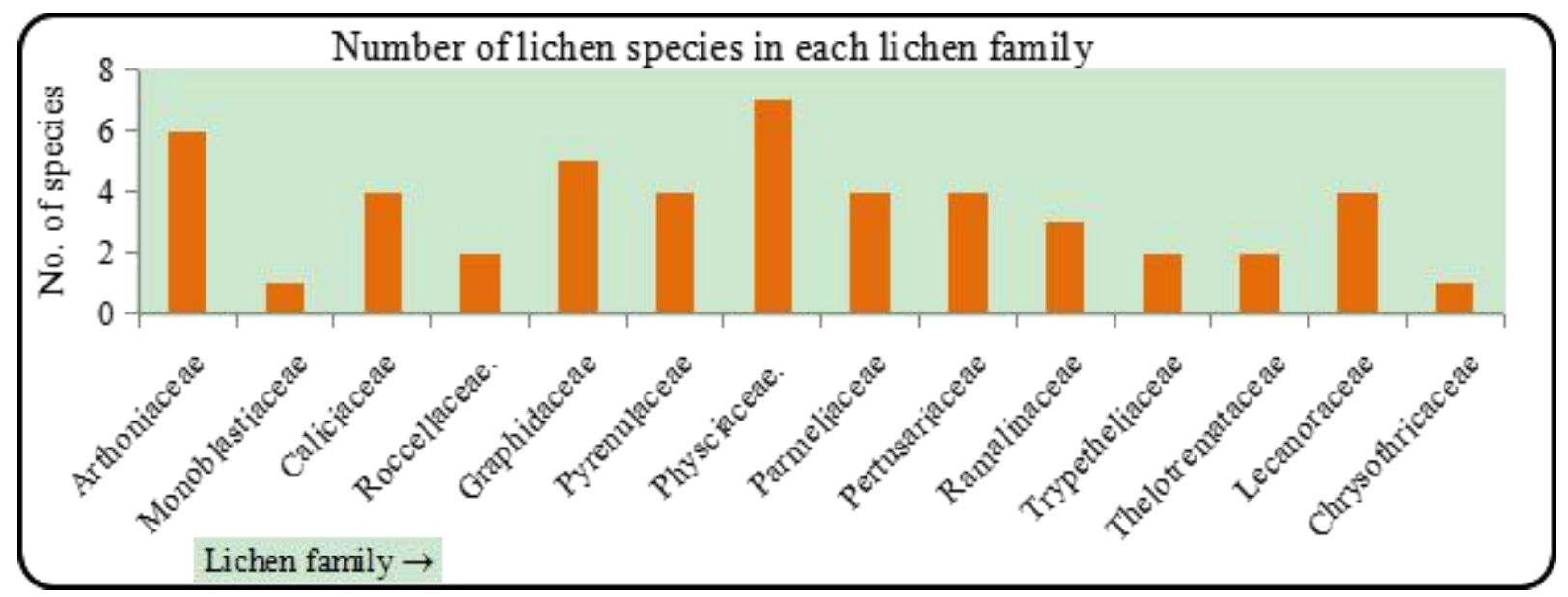

Fig. 3 - Recorded lichen family and number of species of that family, Bhitarkanika NP, (Odisha), India



Fig. 4 - Study sites and number of recorded lichen species of the lichen growth types 


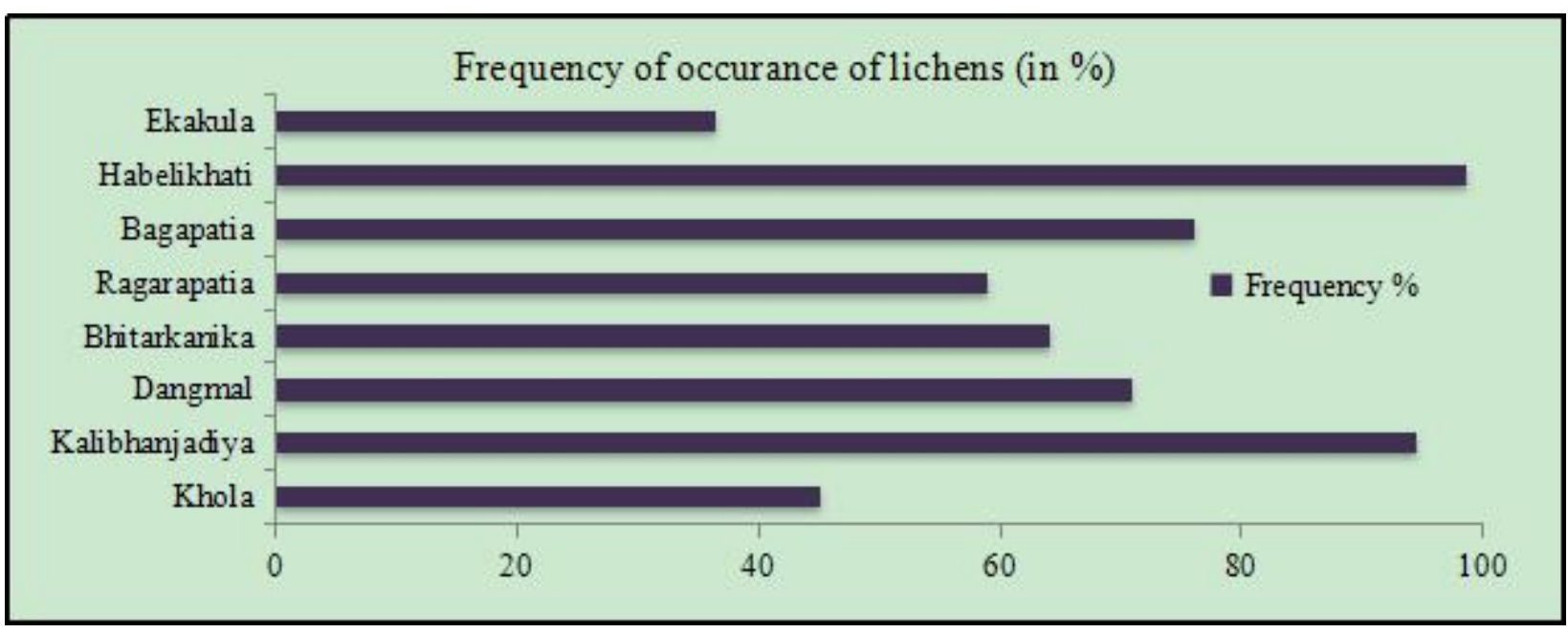

Fig. 5 - Study sites and frequency of lichen occurrence par plant in $\%$

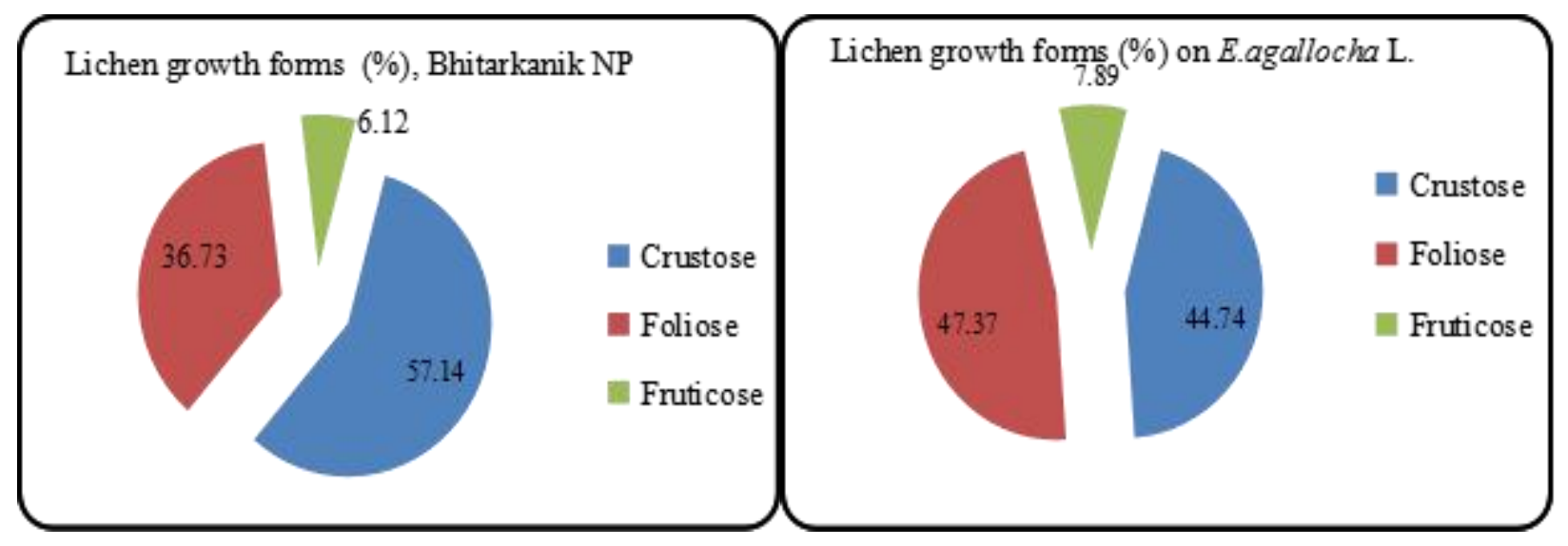

Fig. 6 - Lichen types in\%, Bhitarkanika NP Fig. 7 -Lichen types in $\%$ on E.agallocha L.

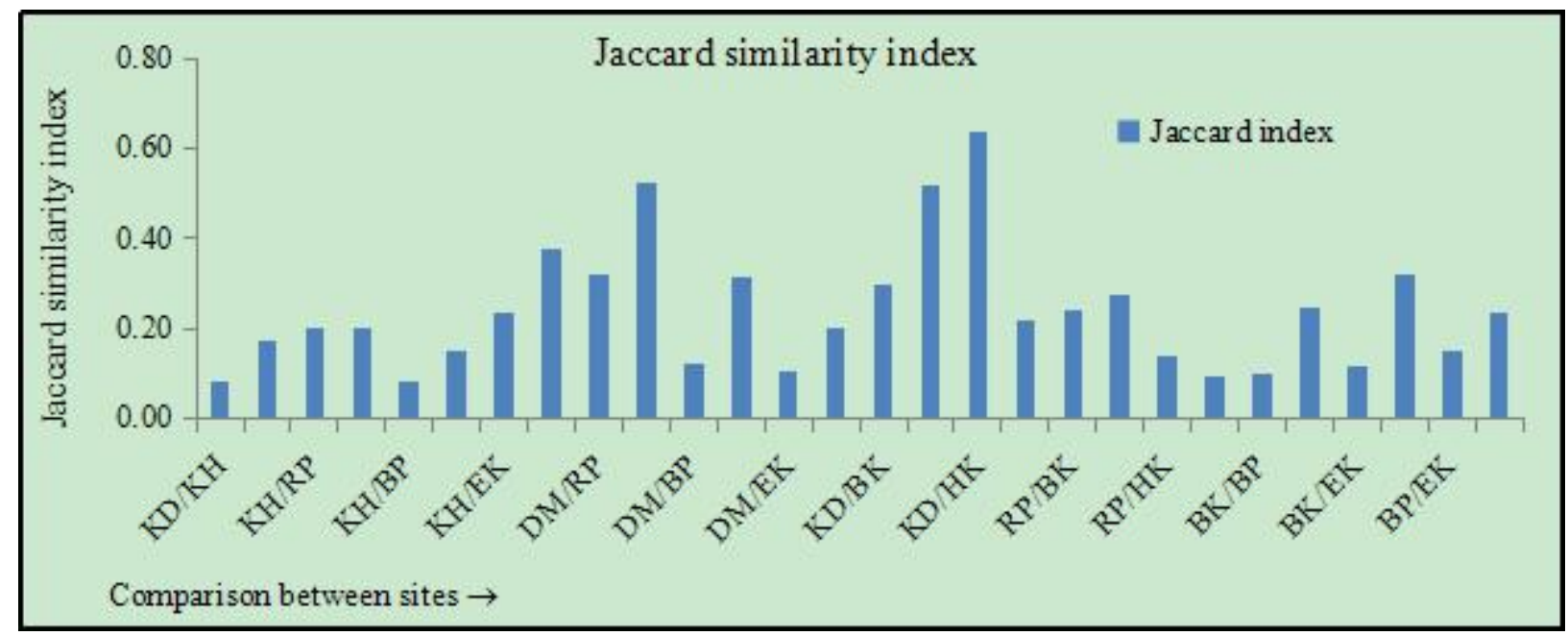

Fig. 8 - Jaccard site similarity index of recorded lichen species between the study sites, Bhitarkanika NP (Odisha) India.

(KH - Khola, KI - Kalibhanjadiya Island, DM - Dangmal, BK - Bhitarkanika, RP - Ragarapatia, B-Bagapatia, HK Habelikhati, EK - Ekakula) 


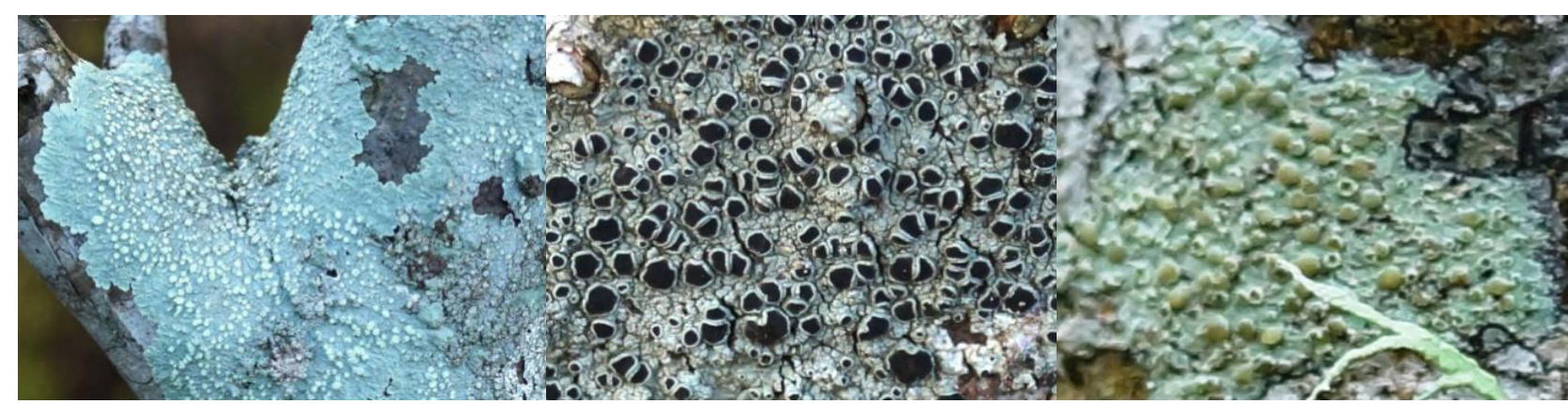

(1)

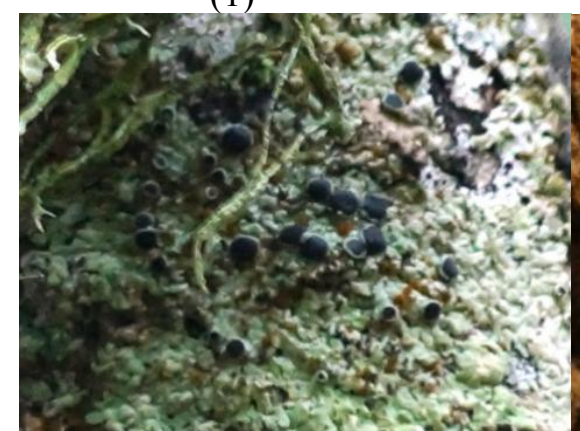

(4)
(2)



(5)
(3)

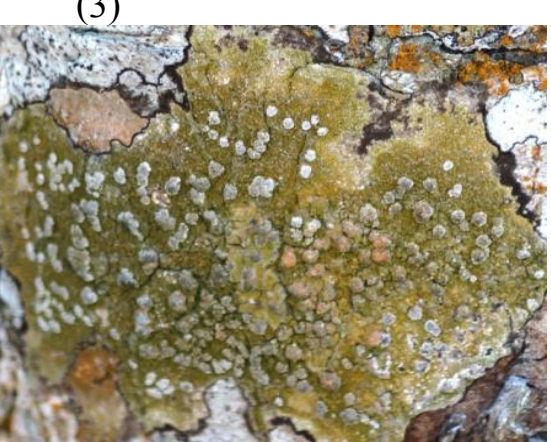

(6)

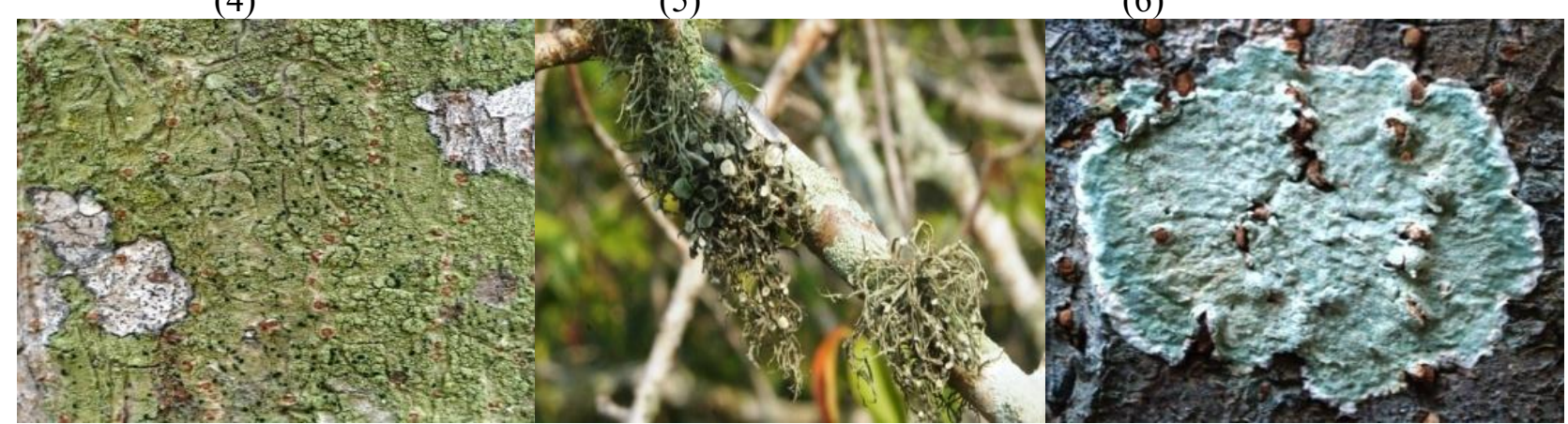

(7)

(8)



(10)

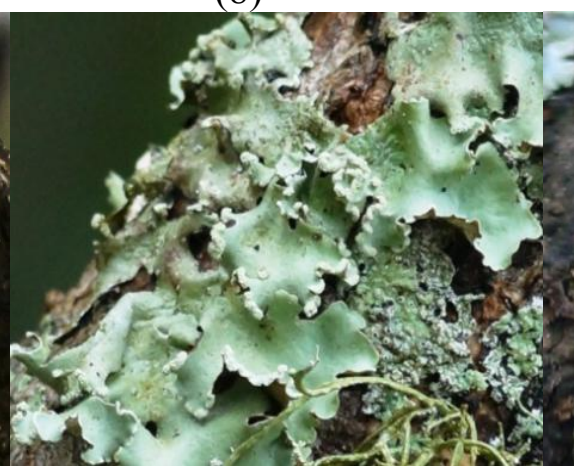

(11)
(9)

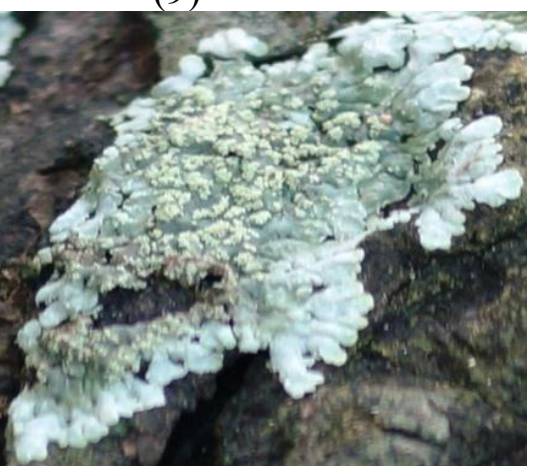

(12)



(13)

(14)

(15)

(16)

Fig. 9 - Lichens on stem \& trunk surface of E.agallocha, Bhitarkanika NP.

1. Dirinaria picta 2. Lacanora tropica 3. Lacanora spp. 2 4. Lacanora spp. 3 5. Dirinaria aegialita 6. Portusaria spp.

7. Pyrrhospora quernea 8. Ramalina calicaris 9.Cryptothecia scripta 10. Physcia pumilior 11. Permotrema spp.

12. Pyxine sorediata 13. Parmotrema spp. 14. Pyrenula spp. 15. Graphis scripta 16. Ramalina calicaris 


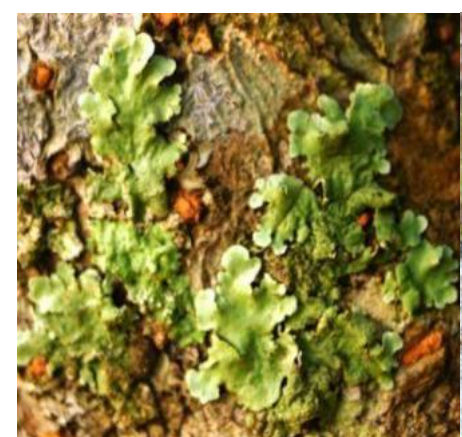

(17)

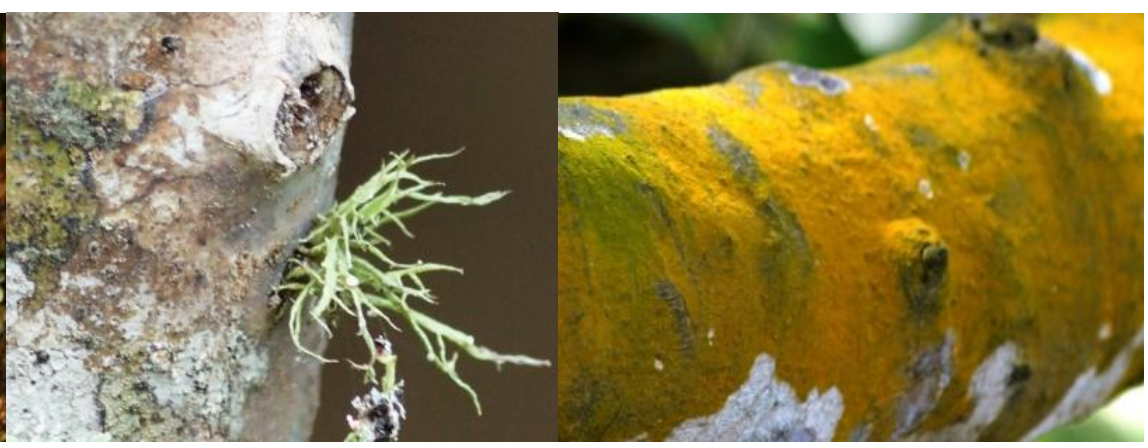

(18)
(19)

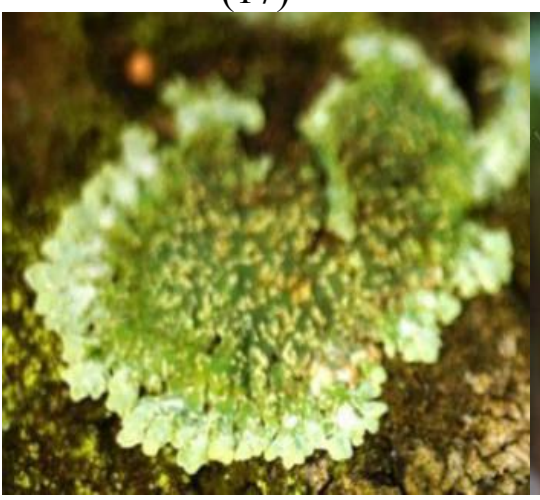

(20)



(21)

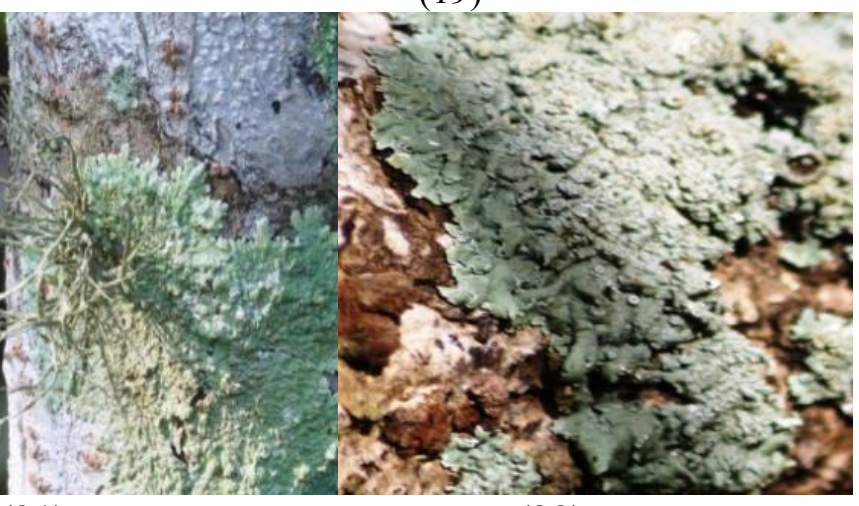

(22)

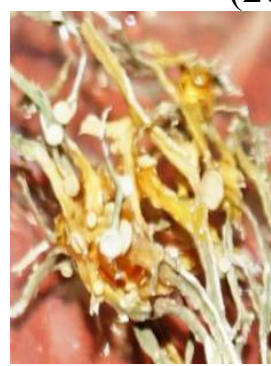

(23)

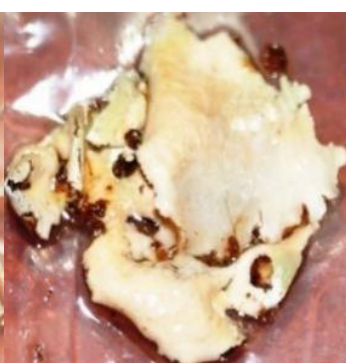

(24)

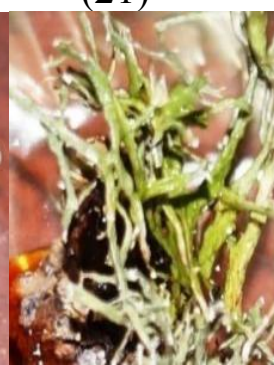

(25)

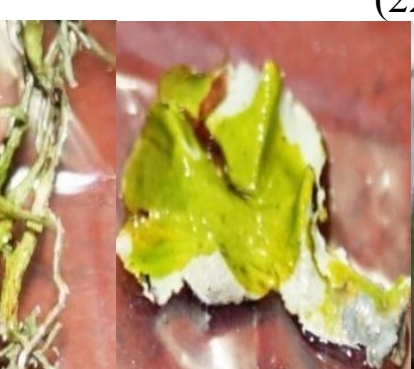

(26)

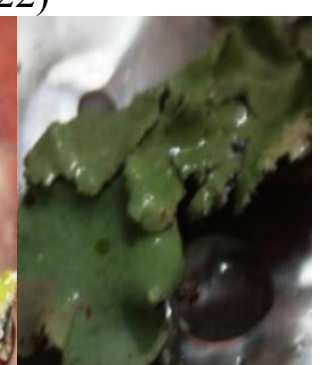

(27)

Fig. 10 - Lichens on stem \& trunk surface of E.agallocha (17, 20, 21 \& 22), A. marina (18), A.officinalis (19), Color change for lichen identification during spot test (23-27).

17. Parmelia sulcata. 18. Pyrenola spp. \& Ramalina spp. 19. Chrysothrix spp. on branch of A.officinalis 20. Pyxine spp. 21. Lichen succession. 22. D. confluens. 23. Ramalina spp. (After treatment $\mathrm{KNO}_{3}$ ). 24. Permotrema spp. (after treatment $\mathrm{KNO}_{3}$ ). 25. Ramalina spp. (After treatment of $\mathrm{KOH}$ ). 26. Permotrema spp. (After treatment of $\mathrm{KOH}$ ). 27. Permotrema spp. (After treatment of $\mathrm{KOH}+\mathrm{KI}$ ).

Table 1 Lichen species, taxonomic family, host mangrove species, growth type and site of occurrence

\begin{tabular}{|c|c|c|c|c|}
\hline $\begin{array}{l}\text { Si. } \\
\text { No. }\end{array}$ & Name of lichen species & Family & $\begin{array}{l}\text { Lichen } \\
\text { type }\end{array}$ & Host Mangrove species (recorded sites) \\
\hline 1 & Arthonia conferta $(\mathrm{Fee}) \mathrm{Nyl}$ & Arthoniaceae & Crustose & E.agallocha $(\mathrm{HK})$ \\
\hline 2 & Arthonia dispersula Nyl. & Arthoniaceae & Crustose & E.agallocha $(\mathrm{HK}, \mathrm{EK})$ \\
\hline 3 & Arthonia radiata (Pers.) Ach. & Arthoniaceae & Crustose & E.agallocha \& H.fomes (DM,BK,KH,RP) \\
\hline 4 & Arthothelium spp. & Arthoniaceae & Crustose & (HK,KI,DM,BP), \\
\hline
\end{tabular}




\begin{tabular}{|c|c|c|c|c|}
\hline $\begin{array}{l}\text { Si. } \\
\text { No. }\end{array}$ & Name of lichen species & Family & $\begin{array}{l}\text { Lichen } \\
\text { type }\end{array}$ & Host Mangrove species (recorded sites) \\
\hline 5 & Cryptothecia scripta G.Thor & Arthoniaceae & Crustose & $\begin{array}{l}\text { E.agallocha (HK,KI,DM, RP), B.cylindrica } \\
\text { \& R.mucronata }(\mathrm{HK}, \mathrm{EK})\end{array}$ \\
\hline 6 & Cryptothecia striata Thor. & Arthoniaceae & Crustose & $\begin{array}{l}\text { E.agallocha (DM, BK, EK), A.officinalis } \\
\text { (DM, HK,KH,BK), C.iripa (HK,DM) }\end{array}$ \\
\hline 7 & $\begin{array}{l}\text { Diploicia canescens (Dicks.) } \\
\text { A.Massal }\end{array}$ & Caliciaceae & Foliose & E.agallocha (HK, KI, EK) \\
\hline 8 & $\begin{array}{l}\text { Dirinaria aegialita (Afz.) B. } \\
\text { Moore }\end{array}$ & Caliciaceae & Foliose & $\begin{array}{l}\text { E.agallocha (KI, DM,BP,HK, RP), H.fomes } \\
(\mathrm{HK})\end{array}$ \\
\hline 9 & $\begin{array}{l}\text { Dirinaria confluens (Fr.) D. D. } \\
\text { Awasthi }\end{array}$ & Caliciaceae & Foliose & E.agallocha (KI,DM, RP, BK) \\
\hline 10 & $\begin{array}{l}\text { Dirinaria picta (Sw.) Clem. \& } \\
\text { Schear }\end{array}$ & Caliciaceae & Foliose & $\begin{array}{l}\text { E.agallocha } \quad \text { (KI,BP, EK), L.racemosa } \\
\text { (KI,HK) }\end{array}$ \\
\hline 11 & Chrysothrix spp. & Chrysothricaceae & Crustose & All sites on A.officinalis \\
\hline 12 & Diorygma spp. & Graphidaceae & Crustose & $\begin{array}{l}\text { E.agallocha (KI,HK,DM,BK), A.officinalis } \\
\text { (DM,BK) }\end{array}$ \\
\hline 13 & $\begin{array}{l}\text { Graphis elegans (Borrer ex } \\
\text { Sm.) Ach }\end{array}$ & Graphidaceae & Crustose & A.officinalis \&C.decandra $(\mathrm{HK}, \mathrm{KI})$ \\
\hline 14 & Graphis intricate Fee. & Graphidaceae & Crustose & $\begin{array}{l}\text { A.marina (HK,KI,BP), H.fomes \&C.iripa } \\
\text { (HK,DM,KI,RP) }\end{array}$ \\
\hline 15 & $\begin{array}{l}\text { Graphis nuda (Magn. ) Staiger } \\
\text { \& Luecking }\end{array}$ & Graphidaceae & Crustose & E.agallocha $(\mathrm{HK}, \mathrm{KI}, \mathrm{BP}, \mathrm{EK})$ \\
\hline 16 & Graphis scripta (L.) Ach. & Graphidaceae & Crustose & E.agallocha $(\mathrm{HK}, \mathrm{KI}, \mathrm{BP})$, K.candel $(\mathrm{KH})$ \\
\hline 17 & Lecanora achora Ach. & Lecanoraceae & Foliose & E.agallocha (KI, EK) \\
\hline 18 & $\begin{array}{l}\text { Lecanora campestris (Schaer.) } \\
\text { Hue }\end{array}$ & Lecanoraceae & Foliose & E.agallocha $(\mathrm{HK})$ \\
\hline 19 & Lecanora tropica Zahlbr. & Lecanoraceae & Foliose & E.agallocha $(\mathrm{HK}, \mathrm{KI})$, \\
\hline 20 & $\begin{array}{l}\text { Anisomeridium biforme (Borrer) } \\
\text { R. C. Harris }\end{array}$ & Monoblastiaceae & Crustose & X.granatum (DM), C.iripa (DM,BK,KI) \\
\hline 21 & Parmelia saxatilis (L.) Ach. & Parmeliaceae & Foliose & E.agallocha (HK,KI,DM,BK) \\
\hline 22 & Parmelia sulcata Taylor & Parmeliaceae & Foliose & E.agallocha (HK,KI,BP, EK) \\
\hline 23 & Parmotrema indicum Hale. & Parmeliaceae & Foliose & E.agallocha $(\mathrm{HK}, \mathrm{KI}, \mathrm{BP}, \mathrm{RP})$ \\
\hline 24 & $\begin{array}{l}\text { Parmotrema mesotropum (Müll. } \\
\text { Arg.) Hale }\end{array}$ & Parmeliaceae & Foliose & E.agallocha (HK,KI,BP) \\
\hline 25 & Ohrolechia spp. & Pertusariaceae & Crustose & E.agallocha $(\mathrm{HK}, \mathrm{KI}, \mathrm{DM}, \mathrm{BK})$ \\
\hline 26 & Pertusaria amaia (Ach.) Nyl & Pertusariaceae & Crustose & $\begin{array}{l}\text { E.agallocha (HK,KI,DM,BK), C.decandra } \\
(\mathrm{KI}, \mathrm{HK}, \mathrm{BK})\end{array}$ \\
\hline 27 & $\begin{array}{l}\text { Pertusaria multipuncta (Turner) } \\
\text { Nyl. }\end{array}$ & Pertusariaceae & Crustose & $\begin{array}{l}\text { E.agallocha (HK,KI,DM,BK), A.officinalis } \\
\text { (KH,DM,BK) }\end{array}$ \\
\hline 28 & $\begin{array}{l}\text { Pertusaria psoromica A. W. } \\
\text { Archer \& Elix }\end{array}$ & Pertusariaceae & Crustose & $\begin{array}{l}\text { E.agallocha } \quad(\mathrm{HK}, \mathrm{KI}, \mathrm{DM}, \mathrm{BK}), \quad \text { A.marina } \\
\text { (HK) }\end{array}$ \\
\hline 29 & $\begin{array}{l}\text { Phaeophyscia hispidula (Ach.) } \\
\text { Essl. }\end{array}$ & Physciaceae & Foliose & E.agallocha (HK,KI,BP, RP) \\
\hline 30 & $\begin{array}{ll}\text { Phaeophyscia } & \text { orbicularis } \\
\text { (Necker) Moberg } & \end{array}$ & Physciaceae & Foliose & E.agallocha $(\mathrm{HK}, \mathrm{KI}, \mathrm{BP})$ \\
\hline 31 & $\begin{array}{l}\text { Physcia aipolia (Ehrh. ex } \\
\text { Humb.) Furnr. }\end{array}$ & Physciaceae & Foliose & E.agallocha $(\mathrm{HK}, \mathrm{BP})$ \\
\hline 32 & Physcia pumilior R. C. Harris & Physciaceae & Foliose & E.agallocha (HK) \\
\hline 33 & $\begin{array}{l}\text { Physcia sorediosa (Vainio) } \\
\text { Lynge }\end{array}$ & Physciaceae & Foliose & E.agallocha (HK,KI,BP) \\
\hline 34 & $\begin{array}{l}\text { Pyrrhospora quernea (Dickson) } \\
\text { Korber }\end{array}$ & Physciaceae & Crustose & $\begin{array}{l}\text { X.granatum }(\mathrm{DM}, \mathrm{KH}), \\
(\mathrm{KH}, \mathrm{DM}, \mathrm{RP})\end{array}$ \\
\hline
\end{tabular}




\begin{tabular}{|c|c|c|c|c|}
\hline $\begin{array}{l}\text { Si. } \\
\text { No. }\end{array}$ & Name of lichen species & Family & $\begin{array}{c}\text { Lichen } \\
\text { type }\end{array}$ & Host Mangrove species (recorded sites) \\
\hline 35 & Pyxine sorediata (Ach.) Mont & Physciaceae & Foliose & E.agallocha $(\mathrm{HK}, \mathrm{KI}, \mathrm{DM})$ \\
\hline 36 & Pyxine spp.2 & Physciaceae & Foliose & E.agallocha (BP) \\
\hline 37 & Pyrenula brunnea Fee & Pyrenulaceae & Crustose & $\begin{array}{l}\text { E.agallocha (HK,DM), X.granatum \& } \\
\text { C.iripa (DM,BK) }\end{array}$ \\
\hline 38 & Pyrenula glabrescens Vain. & Pyrenulaceae & Crustose & E.agallocha $(\mathrm{HK}, \mathrm{KI}, \mathrm{BP})$, L.racemosa $(\mathrm{HK})$ \\
\hline 39 & $\begin{array}{l}\text { Pyrenula microcarpa Mull. } \\
\text { Arg. }\end{array}$ & Pyrenulaceae & Crustose & $\begin{array}{l}\text { A.marina, A.alba (HK), R.mucronata (HK, } \\
\text { KH,EK) }\end{array}$ \\
\hline 40 & Pyrenula spp. 4 & Pyrenulaceae & Crustose & E.agallocha, A.officinalis (HK, KH,EK) \\
\hline 41 & Ramalina calicaris (L.) Fr & Ramalinaceae & Fruticose & E.agallocha $(\mathrm{HK}, \mathrm{KI})$ \\
\hline 42 & Ramalina fraxinea (L.) Ach. & Ramalinaceae & Fruticose & E.agallocha $(\mathrm{HK}, \mathrm{KI})$, A. marina $(\mathrm{HK})$ \\
\hline 43 & Ramalina leiodea (Nyl.) Nyl. & Ramalinaceae & Fruticose & E.agallocha $(\mathrm{HK}, \mathrm{KI})$ \\
\hline 44 & Enterographa spp. & Roccellaceae. & Crustose & E.agallocha (HK), C.decandra (HK) \\
\hline 45 & Opegrapha spp. & Roccellaceae & Crustose & L.racemosa $(\mathrm{HK})$, X.granatum $(\mathrm{BK}, \mathrm{KH})$ \\
\hline 46 & Myriotrema spp. & Thelotremataceae & Crustose & A.marina (EK,BP, KI) \\
\hline 47 & Ocellularia spp. & Thelotremataceae & Crustose & A.marina (EK) \\
\hline 48 & Astrothelium scorioides Nyl. & Trypetheliaceae & Crustose & L.racemosa $(\mathrm{HK})$ \\
\hline 49 & $\begin{array}{l}\text { Astrothelium } \\
\text { cinnamomeum (Eschw.) Mull. } \\
\text { Arg. }\end{array}$ & Trypetheliaceae & Crustose & A.marina (BP, BK, RP) \\
\hline
\end{tabular}

(KH- Khola, KI- Kalibhanjadiya island, DM- Dangmal, BK- Bhitarkanika, RP- Ragarapatia, BP- Bagapatia, HKHabelikhati, EK- Ekakula)

Table 2 Study sites, mangrove plants and number of lichen species recorded with growth forms, Bhitarkanika National Park (Odisha), India

\begin{tabular}{|c|c|c|c|c|c|c|c|c|c|c|}
\hline \multirow[t]{2}{*}{$\begin{array}{l}\text { Si. } \\
\text { No. }\end{array}$} & \multirow[t]{2}{*}{ Host Mangrove species } & \multirow[t]{2}{*}{$\begin{array}{l}\text { No of } \\
\text { species } \\
\text { recorded }\end{array}$} & \multicolumn{8}{|c|}{$\begin{array}{l}\text { Lichen Growth forms at different sites }\{\text { Present } \\
(+) \text { or absent }(\times)[\text { Crustose-Foliose-Fruticose, } \\
\text { respectively]\}, blank=plant not found, N=plant } \\
\text { found but lichen not recorded }\end{array}$} \\
\hline & & & KH & KI & DM & BK & $\mathbf{R P}$ & BP & HK & EK \\
\hline 1 & Excoecaria agallocha $\mathrm{L}$. & 38 & $+x \times$ & +++ & $+x \times$ & $++x$ & $++x$ & $++x$ & +++ & $++x$ \\
\hline 2 & Heritiera fomes Buch.-Ham. & 3 & $+x \times$ & $+x x$ & $+x x$ & $+x x$ & $+x x$ & $\mathrm{~N}$ & $++x$ & \\
\hline 3 & Avicennia officinalis L. & 5 & $+x \times$ & $+x \times$ & $+x x$ & $+x x$ & $+x x$ & $+x x$ & $+x x$ & $+x x$ \\
\hline 4 & Avicennia marina Vierh. & 5 & & $+x \times$ & & $+x \times$ & $+x \times$ & $+x x$ & $+x+$ & $+x \times$ \\
\hline 5 & Avicennia alba Blume & 1 & & & & & & $x \times x$ & $+x \times$ & $\mathrm{N}$ \\
\hline 6 & Rhyzophora mucronata Lam. & 2 & $+x \times$ & $\mathrm{N}$ & & & & $+x \times$ & $+x \times$ & $+x \times$ \\
\hline 7 & Lumnitzera racemosa Willd & 4 & & $+\times x$ & & & & & $++\times$ & \\
\hline 8 & Bruigeriacylindrical L. Blume & 1 & & & & & & & $+x \times$ & \\
\hline 9 & Ceriops decandra (Griff.) Ding Hou & 2 & & $+x \times$ & & $+x x$ & & & $+x \times$ & $\mathrm{N}$ \\
\hline 10 & Kandelia candel L. Druce & 2 & $+x \times$ & & $+x \times$ & & $+x \times$ & $\mathrm{N}$ & & \\
\hline 11 & Xylocarpus granatum Koeing & 4 & $+\times x$ & & $+\times x$ & $+\times x$ & $\mathrm{~N}$ & & & \\
\hline 12 & Cynometra iripa Kostel & 5 & & $+\times x$ & $+\times x$ & $+\times x$ & $+\times x$ & & & \\
\hline
\end{tabular}

(KH- Khola, KI- Kalibhanjadiya Island, DM- Dangmal, BK- Bhitarkanika, RP- Ragarapatia, BP- Bagapatia, HKHabelikhati, EK- Ekakula)

\section{Discussion}

The present recorded lichen species and their growth form percentages showed close similarity as studied at Manipur state, North Eastern India (Jagadeesh Ram 2006, Devi et al. 2015). 
The most common crustose lichen families which were more frequent of occurrence are from Pyrenulaceae, Graphidaceae, Arthoniaceae, Pertusariaceae and Lecanoraceae as recorded by Sethy (2015). The type of lichens and its host mangrove species of Bhitarkanika NP was found different than studied at Pichavaram and Muthupet mangroves (Logesh et al. 2012). Out of presently recorded 49 lichen species, mangrove species E. agallocha was found to host $38(77.55 \%)$ lichen species which is higher than any other mangrove species as studied in Sundarban and Muthupet mangroves (Jagadeesh Ram 2006, Logesh et al. 2013), respectively. From our present study it was found that the crustose lichens prefer to grow on mangrove species like A. officinalis, A. marina, E. agallocha with smooth surface and lenticels on their trunk and stem than the mangroves with fissured bark like $H$. fomes, $L$. racemosa, X. granatum.

Foliose lichens were recorded from the family Caliciaceae, Lecanoraceae, Physciaceae and Parmeliaceae which showed mangrove species specificity. The recorded fruticose lichens were only from the lichen family Ramalinaceae. The lichen species of both foliose and fruticose forms were found to occur abundantly on the surface of E. agallocha at Kalibhanjadiya Island and Habelikhati of Bhitarkanika NP. The sites which showed luxuriant growth of lichens and more diverse type of lichen species were due to the presence of mangrove species like E. agallocha, H. fomes, A. officinalis and $C$. iripa. The presence of numerous lenticels and the peculiar texture of the mangrove species, E. agallocha were found to be possible factors which favored for hosting of highest number of lichen species. The distribution pattern of E. agallocha also favored for the luxuriant lichen growth on its surface as the mangrove is a landward species and supports the work of Vinayaka et al. (2016). The site Ekakula with low frequency of lichen occurrence is thought to be due to high and frequent tidal ingression of saline sea water and surrounding environment which restricted growth of lichens. The site like Habelikhati and Kalibhanjadiya Island with high lichen growth and species diversity showed these sites have suitable condition for lichen establishment. Field information and the results showed these two sites were less influenced by anthropogenic activities and the healthy and old mangrove plants favored the luxuriant growth of lichens (Tiwary \& Prajapati 2015).

The sites like Khola, Dangmal and Bhitarkanika were ecotourism regions of Bhitarkanika NP and influenced by vehicles, tourists and boats. Low lichen diversity of these sites and absence of foliose and fruticose lichens can be linked as these sites with more human interference and unsuitable environment for lichen establishment (Stevens 1979, Rout et al., 2010, Shukla et al. 2014).

\section{Acknowledgments}

The authors are thankful to PCCF, Wild Life (Odisha), DFO- Rajnagar and all other staffs of mangrove forest division, Bhitarkanika Wildlife Sanctuary and National Park, for their support and help during field study.

\section{References}

Awasthi DD. 1991 - A key to microlichens of India, Nepal and Sri Lanka. Bibliotheca Lichenologica 40, 1-337.

Barik J, Chowdhury S. 2014 - True Mangrove Species of Sundarbans Delta, West Bengal, Eastern India. Check List 10(2), 329-334.

Broad K. 1989 - Lichens in southern woodlands. Forestry Commission Handbook 4.

Devi RKS, Rout J, Upreti DK, Nayaka S, Pinokiyo A. 2015 - New records of lichens from Manipur State, North-eastern India. Mycosphere 6 (6), 796-813.

Dey AK, Mishra KG, Rout J, Upreti DK. 2015 - An enumeration of epiphytic lichens from Hojaisub-division of Nagaon district, Assam, India. International Journal of Advanced Research in Biological Science 2(10), 111-115.

Gilbert O. 2004 - Lichens. Scottish Natural Heritage. 
Goward T, McCune B, Meidinger D. 1994 - The Lichens of British Columbia, Illustrated Keys, Part-1: Foliose and Squamulose Species. Province of British Columbia, Research Program Ministry of Forests, 31 Bastion Square Victoria.

Hogarth PJ. 2015 - The biology of mangroves and Seagrasses. Oxford University Press, New York. Jagadeesh Ram TAM. 2006 - Investigation on the lichen flora of Sundarbans Biosphere Reserve, West Bengal. Gauhati University, Assam. http://hdl.handle.net/10603/69542.

Logesh AR, Selvam KM, Upreti DK, Nayaka S, Kathiresan K. 2013 - Mangroves, an Abode for Unique Lichens. Coastal Ecosystems of India, Environmental Information System Center (ENVIS), CAS in Marine Biology, Annamalai University, Tamilnadu, India.

Logesh AR, Upreti DK, Kalaiselvam M, Nayaka S, Kathiresan K. 2012 - Lichen flora of Pichavaram and Muthupet mangroves (Southeast Coast of India). Mycosphere /3/6/1, 884 888.

McCune B. 2012 - Key to the Lichen Genera of the Pacific Northwest. Dept. Botany \& Plant Pathology, Oregon State University.

Muthukumar S, Tarar JL. 2006 - Lichen Flora of Central India. DATTSONS, J. Neheru Marg Sadar, Nagpur.

Nash TH. 2008 - Lichen biology. Cambridge University Press.

Nayak SK, Bajpai R, Upreti DK, Satapathy KB. 2016 - Diversity of lichen flora of Odisha, IndiaAreview. Studies in Fungi 1(1), 114-124.

Nayaka S, Upreti DK, Ingle KK. 2012 - Mangroves of India: Potential Habitats for Unique Lichen Flora. Marine biodiversity, 68-74.

Rai H, Upreti DK. 2014a - Terricolous Lichens in India, Volume 1: Diversity Patterns and Distribution Ecology. Springer Science+Business Media, New York.

Rai H, Upreti DK. 2014b - Terricolous Lichens in India, Volume 2: Morphotaxonomic Studies. Springer Science+Business Media, New York.

Rout J, Das P, Upreti DK. 2010 - Epiphytic lichen diversity in a Reserve Forest in southern Assam, northeast India. Tropical Ecology 51(2), 281-288.

Roy SD, Krishnan P, George, G, Kaliyamoorthy, M, Bharthi, MPG. 2009 - Mangroves of Andaman and Nicobar Islands. Central Agricultural Research Institute, ICAR Port Blair.

Sahu SC, Suresh HS, Murthy IK, Ravindranath NH. 2015 - Mangrove Area Assessment in India:Implications of Loss of Mangroves. J Earth Sci Clim Change 6(5), 1-7.

Sethy P, Pandit G, Sharma B. 2012 - Lichens on mangrove plants in Andaman Islands, India. Mycosphere /3/4/11, 476-484.

Sethy PP. 2015 - Occurrence of Lichen Flora on Mangrove Plants in Adaman Island. Journal of Basic Sciences 2, 132-134.

Sethy, PP, Pandit G, Sharma, B. 2014 - New records of lichens on Mangrove in the Andaman Islands of India. Paripex- Indian Journal of Research 3 (9), 6-8.

Shukla V, Upreti DK, Bajpai R. 2014 - Lichens to Biomonitor the Environment. Springer.

Singh KP, Sinha GP. 2010 - Indian lichens: An annotated checklist. Botanical Survey of India.

Singh P, Singh KP, Bhatt AB. 2015 - Diversity and distribution of microlichens in the state of Arunachal Pradesh, Eastern Himalaya, India. Check List 11(6), 1-20.

Stevens GN. 1979 - Distribution and Related Ecology of Macrolichens on Mangroves on the East Australian Coast. The Lichenologist 11, 293-305.

Stiling PD. 2012 - Ecology: Global Insights \& Investigations. The McGraw-Hill Companies, Inc.

Tiwari SC, Prajapati A. 2015 - Lichen as Indicator of Forest Health Status in Achanakmar Amarkantak Biosphere Reserve. International Journal of Research Studies in Biosciences (IJRSB) 3(4), 70-79.

Vinayaka KS, Chetan HC, Mesta AR. 2016 - Diversity and Distribution Pattern of Lichens in the Mid Elevation Wet Evergreen Forest, Southern Western Ghats, India. International Journal of Research Studies in Biosciences (IJRSB) 4(1), 15-20.

Weerakoon G. 2015 - Fascinating Lichens of Sri Lanka. Colombo, Sri Lanka: Ceylon Tea Services PLC. 